\title{
Mental Heath in Womens and its Treatment by Tissue Remedies
}

\author{
Balaji Deekshitulu PV* \\ Department of Psychology, Drvidian University, India
}

Submission: November 22, 2016; Published: January 30, 2017

*Corresponding author: : Balaji Deekshitulu PV, Department of Psychology, Lecturer in Psychology \& Psychologist and Alt. Medicine (homeopathy) Practitioner, Tirupati, India, Tel: 8885391722; Email: drsribalaji@gmail.com

\begin{abstract}
In this article the author argues that complete presentation of Psychosomatic disorders in general, is used to mean a healthy balance of the mind and body in an overall feeling of well-being to describing the existence of positive health in an individual as exemplified by quality of life, Tissue remedies it is like rejuvenation and cleanup process on all levels physical, mental and emotional. The concept of Psychosomatic Problems of mind and these determine Homeopathy is guided best treatment. Tissue remedies are highlighted as a holistic system with its concern for prevention and promotion of psychosomatic disorders and mental health.
\end{abstract}

Keywords: Anxiety; Stress; Depression etc.; Mental health and Tissue remedies

\section{Introduction}

Psychological problems, discomforts, illnesses are on a rise in the present era, particularly in women. Today's women have house work as well as jobs to handle. The 21st century woman holds fast to her responsibilities both at home and job front. Balancing her responsibilities as a Mother, a Wife, a Sister, a Daughter, a Daughter-in-law and above all as an officegoing employee she has no time for herself. No time to relax. This makes the present women more susceptible to emotional problems. The most common complaints found in clinical practice now-a-days, are depression and anxiety but emotional problems such as anger, frustration, loss of self-confidence and guilt are also seen. You are more vulnerable to these difficulties, if you have an unsatisfactory upbringing but that does not mean that people with happy childhood do not suffer from emotional stress. Emotional problems are most easily recognized and accepted, when they are precipitated by an obvious event, such as bereavement, job loss or marital break down. For many women, asking for help is often far from easy but it is important not to suppress your feelings because this can pent up trouble for later.

Some women have the extra difficulty of living through a range of emotional pressures that depend to some extent on their hormone levels They may experience considerable emotional distress as a result of premenstrual syndrome, painful periods, pregnancy, child birth or the menopause. Tissue remedies are particularly well suited in relieving emotional problems; symptomatic medicines will help in the minor ups and downs of life while constitutional treatment has a much wider range of action. The more serious emotional problems should only be treated with Tissue remedies if there is medical supervision. If you are unfortunate enough to suffer from a psychiatric illness, you may still suffer from the same emotional problems as everyone else, and you may find that Tissue remedies will help you through the problems discussed in this article. Some of the common emotional disorders that we see in our daily practice are:

\section{Depression}

Depression is a normal response to a sad event or to a series of mishaps. Depression is indicated by changes in appetite, loss of libido, sleep disturbance and thoughts of suicide, it can often be helped by constitutional prescribing, but this requires medical supervision.

\section{Anxiety}

Anxiety is a perfectly normal emotion and can range from 
a feeling of mild unease to that of intense fear. Anxiety disrupts your everyday activities that it becomes a problem, then it can take over your thoughts and will often lead to an irrational feeling that something bad will happen. Anxiety can cause physical symptoms including palpitations, chest pains muscle tension, digestive upsets, frequency in urination, sweating, blushing, and fatigue. It is important to discuss your symptoms fully with your doctor because so many of these symptoms can also be caused by physical illness

\section{Panic attacks}

The physical symptoms are those of anxiety and may in particular include over breathing (hyper ventilation), which can often be helped by breathing in and out of a paper bag for a few minutes.

\section{Post-Traumatic stress disorder}

This type of anxiety occurs either immediately after a frightening event or some months later, such events includes natural disasters, serious accidents, rape and other violent attacks. The symptoms include feelings of guilt, dreams or recurring memories of the event and a sense of isolation. Tissue remedies are often beneficial for panic attacks and posttraumatic stress.

\section{Phobia}

The word phobia means fear. A phobia only becomes a problem when it interferes with normal life.

\section{Eating disorders}

The relationship between women and food is very complex. A women is expected to be a good cook also to nurture her children by giving them adequate and interesting food as part of being a «good mother». The provision and preparation of food has thus become closely associated with a woman's feelings about her role in life and how well she is doing. On a personal level women can become obsessed by food. Appetite is normally controlled by feelings of hunger before a meal and satisfaction, afterwards it is therefore a meal and satisfaction afterwards, it is therefore not surprising that women often turn to food, when they are feeling depressed or in need of comfort. Obesity is not just the result of over eating; it can result from too much slimming. It has been recognized that, in some women, severe calorie restriction stimulates the body into becoming very efficient so a return to a normal calorie intake after a period of dieting is accompanied by weight gain. A further complication, in western countries at least, is the social pressure to be thinner than is sensible or healthy. Fortunately the growing awareness of healthy eating is creating a more balanced approach to 'slimming' with realistic goals for weight and diets that contain adequate amounts of minerals and vitamins.

\section{Anorexia nervosa and bulimia nervosa}

Are eating disorders that are becoming increasingly common? Anorexia nervosa is a serious disorder much more complicated than a simple loss of appetite and indicates a psychological aversion to food. The disorder usually, but not always, occurs in adolescent girls who fear becoming fat and develop a distorted impression of their own body image. In fact, at the start of the illness, sufferers are often perfectly normal in size and weight. During the illness the menstrual periods often becomes quite irregular and may even stop completely. In anorexia there is an over whelming fear of being fat, so food is avoided and there is a serious, sometimes fatal, loss of weight. In bulimia bouts of over eating are followed by self-induced vomiting, which is usually done in secret. Although bulimics are often of normal, or near normal, weight, they can endanger their lives by becoming dehydrated, the loss of potassium from their bodies can cause weakness.

\section{Drug dependence}

A drug is a chemical substance that is known to alter the way the body functions and/or to change the course of a disease. Such substances are present in tea, coffee, alcohol, and cigarettes and are often used to excess by people under stress, recreational drugs are being increasingly used for relaxation, particularly by young people. Don't depend on stimulants, many people looking for ways to ease the stresses of life turn to caffeine, alcohol and sugar; although this way be beneficial in small amounts in greater quantities, taking in too much caffeine from drinks such as coffee or food such as chocolate can make you feel unwell.

\section{Emotional symptoms}

Person may feel pathetic, worn out and weepy, reluctant to be in company yet not truly on own, vigorous exercise, especially dancing or aerobics or watching a thunder storm may lead to feeling better, may suffer from a loss of libido and dislike being touched sexually, even if feeling over worked will still refuse offers of help.

Table 1: How to use cell salts.

\begin{tabular}{|c|c|c|}
\hline Cell salt & $\begin{array}{c}\text { Mental symptoms } \\
\text { of deficiency }\end{array}$ & $\begin{array}{c}\text { Physical symptoms } \\
\text { of deficiency }\end{array}$ \\
\hline Calc Fluor & Indecisiveness, low self-esteem & Chapped skin, deficient tooth enamel \\
\hline Calc Phos & Mental weakness, lack of motivation & $\begin{array}{c}\text { Nosebleeds, late teeth, headaches in } \\
\text { children }\end{array}$ \\
\hline Calc Sulph & $\begin{array}{c}\text { Fatigue, laziness, worries about imaginary } \\
\text { problems }\end{array}$ & Yellow discharges, boils, open infections \\
\hline
\end{tabular}




\section{Journal of Pharmacology \& Clinical Research}

\begin{tabular}{|c|c|c|}
\hline Ferrum Phos & $\begin{array}{l}\text { Stimulation and overheating followed by } \\
\text { dullness and listlessness }\end{array}$ & $\begin{array}{c}\text { First stages of fever (99-101), sore throat, } \\
\text { nosebleeds, colds, flu }\end{array}$ \\
\hline Kali Mur & $\begin{array}{l}\text { Irritability, apathy, homesickness, } \\
\text { hypochondria }\end{array}$ & $\begin{array}{c}\text { Second stage of fever (101-103), coughing, } \\
\text { white mucus discharges }\end{array}$ \\
\hline Kali Phos & $\begin{array}{l}\text { Nervous tension, extreme nervousness, } \\
\text { moodiness, anger, self-pity }\end{array}$ & Nerve and sleep problems, bad breath \\
\hline Kali Sulph & $\begin{array}{c}\text { Scary dreams, sensitivity to noises, } \\
\text { irritability, anger }\end{array}$ & $\begin{array}{l}\text { Thick yellow discharges, changing } \\
\text { symptoms }\end{array}$ \\
\hline Mag Phos & Sensitivity, impulsiveness & $\begin{array}{l}\text { Cramping and shooting pains, spasms, } \\
\text { hiccoughs }\end{array}$ \\
\hline Nat Mur & Isolation, control issues, deep grief & $\begin{array}{l}\text { Head cold and congestion, watery } \\
\text { discharges, sun sensitivity, cold sores }\end{array}$ \\
\hline Nat Phos & $\begin{array}{c}\text { Depression, sleeplessness, low self- } \\
\text { esteem }\end{array}$ & Acne, blackheads, greasy or brittle hair \\
\hline Nat Sulph & $\begin{array}{l}\text { Depression from wet weather or head } \\
\text { injuries }\end{array}$ & Swollen feet or hands, foul-smelling gas \\
\hline Silicea & $\begin{array}{c}\text { Shyness, lack of "grit," hypersensitivity, } \\
\text { sensitivity to cold }\end{array}$ & Light sensitivity, sweaty hands and feet \\
\hline
\end{tabular}

Review the chart and note if you have any symptoms of deficiency.

\section{What are tissue (cell) salts?}

Dr. Schuessler, a 19-th century German physician, developed the 12 tissue salts, also known as cell salts. They are 12 minerals available in each cell and tissue that are essential to body's metabolism. When these vital tissue salts are in the correct ratio or concentration, the body is healthy. As soon as the tissue salts ratio is disturbed, the proper cell functioning is impaired, resulting in illness. We should get tissue salts through our diet but due to our modern lifestyle, we lose every day minerals through stress, bad nutrition and environmental toxins. Tissue salts are homeopathic dilutions of the mineral salts that our cells need to function properly. Although they not classed as genuine homeopathic preparations, they are offer in low dilutions such as $6 \mathrm{X}$ and $12 \mathrm{X}$ (Table 1).

\section{Prevention and post treatment for mental health}

Take 3 tablets of each salt and let them dissolve in your mouth. For best results use them once daily for 3 or 4 months (or) taken 4 tablets 3 times in per day for quick results. Frederick J. Wulling [1] studies that tissue remedies are good working for physical and psychological health. William Boericke, M. D. and W. A. Dewey, M. D. [2] asked that the Mag Phos, 30, Kali Phos, Clc.phos are extent curing for a prolonged attack of acute and subacute inflammation of the brain like anxiety, stress, and various mental illnesses. Peter Brodhead [3], Robin Murphy [4] asked that the NS, KP, MP, SCILICIA, CP are fundamental remedy we need is based on the day to day stresses we have faced and dealt with. $80 \%$ of classical homeopathy is used in treating that layer.After clearing the fundamental layers we get back to our core constitutional remedy. Amy Henderson [5] asked that the Schuessler Salts or Biochemical Salts are minerals that balance the body functions, and may lead to cures for various illnesses like mentally, the lack of this mineral causes poor memory, incapacity for concentrated thought, and an overall weak mind.
June Sayer [6] study that homeopathy and tissue salts can be of benefit to all ages; it is still important to remember that to get the best results on psychological and physiological diseases.

Aleeze S Moss et al. [7] about that Mood disorders are among the most prevalent mental health issues today and there are many approaches towards their management. While many different types of medication are available, more and more people turn to CAM interventions to help manage their mood disorders. CAM interventions can include herbal remedies. Madeleine Innocent [8] asked that the physical body contains (and requires) 12 inorganic salts, to operate efficiently B-28 include growth disorders, hyper-acidity, prone to infections, skin eruptions, lax tissues leading to prolapses and a multitude of physical and psychological disorders. Iris R Belland Mary Koithan [9] significant that the remedy must be appraised as a salient, but low level, novel threat, stressor, or homeostatic disruption for the whole organism. Silica nanoparticles adsorb remedy source and amplify effects. Snehal singh [10] asked that the remedies are not drugs, but minerals salts that the body naturally contains. They do not suppress a disease, but replenish our tissues and restore normal functioning. E.P. Anshutz [11] asked that Kali phos, Calcarea phos, Magn. Phos are working at brain functions of various mental conditions.

\section{Conclusion}

Tissue salts are safe and effective and a deep healing process which transformed my patient's life over several years, this healing lead both of us away from our short term preoccupation with fighting disease and forced us to pay attention to incorporating the psychosomatic emotional message of illness like including physical, psychological, emotional and psychic, that we were both able to learn the value of trusting the importance of her illness rather than trying to defeat it with cure. Throughout all the discussions and media attacks 
on homoeopathy during the last few years, one thing is never mentioned and that is the extraordinary effectiveness of Bio chemic medicines to treat symptoms relating to psychological problems. These include emotional states such as grief, fright, anguish, anger, indignation, guilt, remorse, disappointed love, homesickness, jealousy. In addition, it can also very successfully treat negative states of mind such as depression, fear, anxiety, shock, panic attacks, phobias and anticipatory anxiety.

\section{References}

1. Frederick J Wulling (1915) Schuessler's twelve tissue remedies. Journal of Pharmaceutical Sciences 4(7): 821-822.

2. W Boericke, WA Dewey, Alan Street (1998) The Twelve Tissue Remedies of Schüssler. B Jain Publishers Pvt Ltd, India.

3. Peter Brodhead (2001) The 12 Tissue Salts or Cell Salt Remedies.
4. Murphy Robin ND (2006) Nature's Materia Medica ( $3^{\text {rd }}$ edn), USA.

5. Amy Henderson (2009) Tissue salts. Health24, South Africa.

6. June Sayer (2010) Homeopathy and Biochemic Tissue (Cell) Salts. UK.

7. Moss AS, Monti DA, Amsterdam JD, Newberg AB (2011) Complementary and Alternative Medicine Therapies in Mood Disorders. Expert Rev Neurothe 11(7): 1049-1056.

8. Madeleine Innocent (2011) A Biochemic Treatment of Disease. Kindle edn.

9. Bell IR, Koithan M (2012) A model for homeopathic remedy effects: low dose nanoparticles, allostatic cross-adaptation, and time-dependent sensitization in a complex adaptive system, BMC Complement Altern Med 12: 191.

10. Snehal singh (2012) The magic of mineral salts. India.

11. EP Anshutz (2015) A Guide to Twelve Tissue Remedies of Biochemistry. 